\title{
Climate Variability on Fishing Activities in Inland Waters: Case of Owena River in Ondo and Osun States, Nigeria
}

\author{
Adeleke Mosunmola Lydia, Jacob Victor Jerry, Desalegn Yayeh Ayal, \\ Akinola Joshua Oluwatobi, Ayodele Idowu Sunday, and \\ Ajibefun Igbekele Amos
}

\section{Contents}

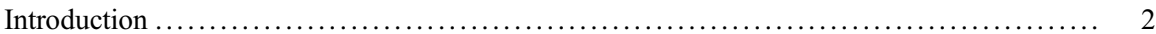

The Chapter Design $\ldots \ldots \ldots \ldots \ldots \ldots \ldots \ldots \ldots \ldots \ldots \ldots \ldots \ldots \ldots \ldots \ldots \ldots \ldots \ldots \ldots \ldots, \quad 4$

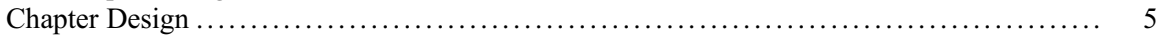

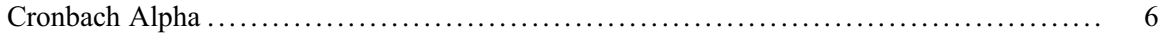

Distribution According to Gender and Age Group of Respondent in Owena Osun and Ondo

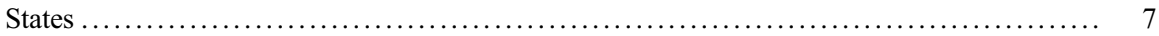

Secondary Occupation and Monthly Income of Respondent in Owena Osun and Ondo State ... 8

Effect of Climate Variability on Fish Catch in Owena Ondo and Osun States .............. 9

Likely Effect of Climate Variability on Fisher Folks in Owena Ondo and Osun States ....... 11

Effect of Climate Variability on Fishing Techniques in Owena Ondo and Osun States ....... 13

Effect of Variability in Climate on Choice of Fishing Equipment in Owena Ondo and Osun

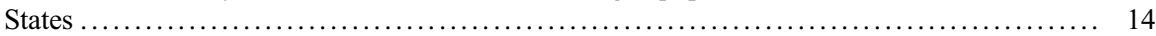

This chapter was previously published non-open access with exclusive rights reserved by the Publisher. It has been changed retrospectively to open access under a CC BY 4.0 license and the copyright holder is "The Author(s)". For further details, please see the license information at the end of the chapter.

A. M. Lydia $(\bowtie) \cdot J$. V. Jerry $\cdot$ A. J. Oluwatobi $\cdot$ A. I. Sunday

Department of Fisheries and Aquaculture Technology, Federal University of Technology, Akure (FUTA), Akure, Nigeria

e-mail: mladeleke@futa.edu.ng

e-mail: jacobvictor402@yahoo.com; joesheathakinola@gmail.com; ayodeleidowusunday@gmail. com

D. Y. Ayal

Center for Food Security Studies, College of Development Studies, Addis Ababa University, Addis Ababa, Ethiopia

e-mail: desalegn.yayeh@aau.edu.et
A. I. Amos
Department of Agricultural and Resource Economics, Federal University of Technology, Akure (FUTA), Akure, Nigeria
e-mail: iaajibefun@futa.edu.ng 
Climatic Trends in Owena River Between 2008 and 2017: Wind Trends and Rainfall Pattern in

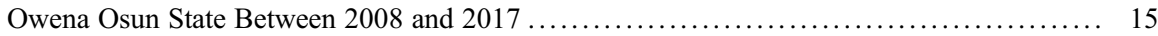

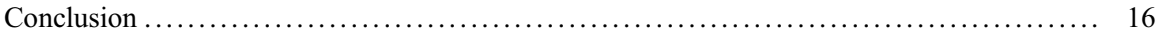

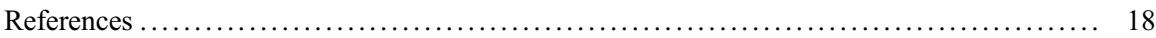

\section{Abstract}

This chapter examined the effects of climate variability on fishing activities in inland waters: the case of Owena River in Ondo and Osun States, Nigeria. The particular inland water body (Owena) was selected purposively because the Owena River crosses across the two States (Ondo and Osun States). A total of 100 respondents/fisher folks were selected randomly. Primary data was used to get information from the respondents with the aid of the structured questionnaire. Secondary data was used to get information on the climate variability existing in the locations in order to achieve the set objectives. Specifically, the effects of climatic variables such as temperature, rainfall, and wind were determined on fisher folk, fishing duration, fish catch, fishing techniques, and fishing equipment/ gears. Descriptive survey design was used to examine the demographic characteristics of respondents. The result revealed that most of the respondents $(96 \%)$ were male. This chapter established that climate variability particularly strong wind, rainfall, and temperature has adverse effects on fishing activities such as reduction in fish catch, long duration of fishing, loss of fishing gear, change in fishing techniques, and effect on health; hence, the livelihoods of the residence are adversely affected on the long run. In addition to the adverse effect of poverty and loss of life for the fisher folks. Although, the fisher folks livelihoods depend mainly on fisheries resources and optimum fishing depends on favorable climate/ weather conditions. Therefore, proper preventive coping strategies against the adverse effect of climate variables should be paramount in both States (Ondo and Ekiti) to improve livelihoods and food security.

\section{Keywords}

Climate variability $\cdot$ Fishing activities $\cdot$ Inland waters $\cdot$ Livelihoods $\cdot$ Nigeria

\section{Introduction}

Climate variability is the observable change in atmospheric conditions of a given area at a particular time usually 10 years. The Intergovernmental Panel on Climate Change defined climate change or variability as any change in climate overtime, whether due to natural variability or as a result of human activities. Temperature and precipitation are the most common climate variables critical to measure with regard to food systems. Climate variability poses a threat to the effective productivity and sustainability of fishing activities and resources around the world. Climate variabilities are changes or variation in climate condition due to factors such as anthropogenic factors, e.g., bush burning, release of fossil fuel, and other biochemical activities which will consequently lead to global warming, loss of abundant fisheries 
resources and other agricultural resources, and also depletion of ozone layer (Cheung et al. 2009).

Climate plays an important role in the world. Because most livelihood and living resources depend on suitable climatic condition for survival and continuity, its effects can be felt directly or indirectly. The Intergovernmental Panel on Climate Change (IPCC) predicted that during the next decades, billions of people, especially those in developing countries, will face changes in rainfall patterns that will contribute to severe water shortages or flooding, rising temperatures that will cause shifts in crop growing season, and aquatic organism distribution.

Climate change and global warming will definitely cause adverse effects on the livelihoods of the populace in Nigeria if not prevented, and it will affect crop production, livestock production, fisheries, forestry, and post-harvest activities, because the rainfall regimes and patterns will be altered, floods which devastate farmlands would occur, increase in temperature and humidity which increases pest and disease would occur, and other natural disasters like floods, ocean, and storm surges, which not only damage Nigerians' livelihood but also cause harm to life and property, would occur.

Nigeria is a West African country found in the tropics; it has only two seasons which are the dry season and the raining season. The country is one of the most populated countries in the world with over 180 million people and is blessed with abundant aquatic resources. However, Nigeria is vulnerable to climate change impacts due to its geography, location, climate, vegetation, soils, economic structure, population and settlement, energy demands, and agricultural activities.

The prominence and persistence of climate change has made it a global menace with adverse effects borne by developing nations (Agbebi and Omoniyi 2011). Global disasters perpetrated by storm-surge, flood, coastal erosion, and other natural hazards have brought much anxiety and bewilderment to the world governing agencies. These impacts and implications are profound as they occur through the increasing changes in water temperature/sea levels (Adeleke and Omoboyeje 2016).

Fisheries is one of the fastest growing sectors in the world, and it provides employment, food, income, and recreation for many people globally. The dependence of the human populace on fishing activities as a major source of food and livelihood is linked to the rich nutritional composition of fisheries products (fish, crayfish, prawn, shrimps, etc.), palatability, digestibility, and high source of animal protein, omega fatty acid, and vitamins.

Despite these numerous and enviable benefits, fisheries resources, functions, and structures have come under intense threat due to the extensive and increasing anthropogenic activities that exist in and around various water bodies. These result in a wide array of problems for both the aquatic resources users and decision makers. These anthropogenic activities often lead to induced climate change which have shown to have apparent effect on aquatic ecosystems, the economic and social system that depends on them (World Fish Centre 2006; Perry et al. 2009).

Recent studies on the effect of climate change on aquaculture production and management in Akure metropolis, Ondo State, and also the occurrences of climate change and its effect on the fishing activities in the coastal region of Ondo State 
(Adeleke and Omoboyeje 2016; Adeleke and Balogun 2013), respectively, have revealed the occurrences of climate variability and its effect on fishing activities through alteration in temperature, wind pattern, rainfall pattern, water qualities, and availability.

Severe effects such as great reduction in aquatic resources, low fish catch, reduced fish production, slow growth rate, increase in boat mishap, loss of lives, poverty, etc. arise mainly from increased flooding, variation in rainfall pattern and intensity, and rising temperature. Idowu et al. (2011) reported that the impacts of climate change are expected to exacerbate the impacts of human pressure which will further diminish the ability of natural ecosystems to continue to provide ecosystem services and may cause invasion of strange species that are favored by climate change thereby threatening biodiversity. Also, poor adaptation strategies and high dependence on fisheries have been reported to expose small-scale fisher folks in most developing country to climate change (Allison et al. 2009). These effects impact on fish species composition, production, and yield, risk of health and life of fisher folk, and loss and damage to livelihood assets. Therefore, the fisher folk will have to seek adaptation and mitigation strategies in order to sustain their livelihood.

The inhabitants of Ondo and Osun are mostly small-scale commercial fish farmers that depend on fisheries resources as a source of food and livelihood. However, climate variability may threaten their livelihood and infrastructural development. Hence, there is the need to identify the pathways through which climate variability and change are impacting or likely to impact the fishing-dependent communities. This will also help policy makers in implementing adaptive strategies to be able to withstand and cope with these adverse climate variability. This research work will examine the effect of climate variability on fishing activities in Owena Ondo and Osun States.

The following research questions were answered in this chapter. What are the effects in Owena, Nigeria, are of temperature, rainfall, and wind variability on fish catch; rainfall, temperature, and wind variability on fishing techniques and equipment; rainfall, temperature, and wind variability on fishing duration; and rainfall, temperature, and wind variability on fisher folks.

\section{The Chapter Design}

The chapter design that is adopted in this chapter is descriptive survey designed to obtain precise information on the current status of climate change and to possibly draw a valid conclusion from the survey. It should be noted that there are no climate change nor meteorological records in the area as observed limitation of the chapter.

Owena Ondo State and Owena Osun State were used. Owena Ondo is located at geographical coordinate $7^{\circ} 12^{\prime} 0^{\prime \prime}$ North, $5^{\circ} 1^{\prime} 0^{\prime \prime}$ East, while Owena Osun is located at latitude 7.19908 and longitude 5.018267 degree. Both areas were purposively selected based on general fishing activities, trading, accessibility, and anthropogenic activities (Figs. 1 and 2). 


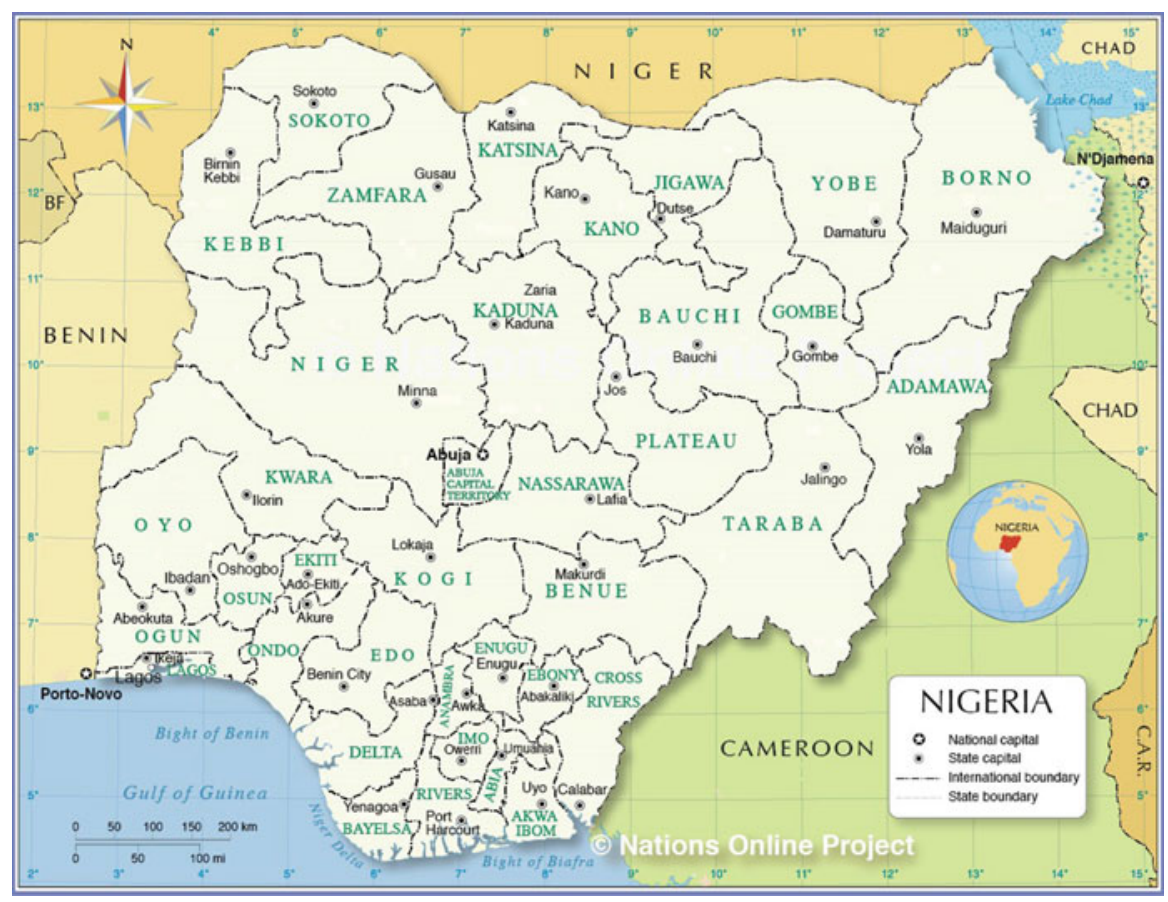

Fig. 1 Map of Nigeria. (Source: Authors' Download: Google map, 2018)

\section{Chapter Design}

A multistage sampling technique was used to select the samples in this chapter. The first stage involved the purposive selection of Owena Ijesa Ori Ade Osun State and Owena Market road Ondo East Local Government and Owena Ondo State. The justification of the selection is based on the fact that the two locations are close and prominent for fishing activities and have the same water body flow to both locations. The target population are fisher folk, and fishermen in Owena Ondo State and Owena Osun State were purposively selected based on their closeness of the site and the prominent fishing activities in the area. Primary data from fisher folks were collected with the aid of an interview schedule using structured questionnaire. 50 questionnaires each were administered to both locations making it 100 in total. The interview schedules were divided into sections based on the objectives of the research. Data obtained from various sources were processed before analysis. The data were edited, coded, and entered for analysis in the Statistical Package for Social Sciences (SPSS). Summary tables were then prepared to facilitate recording and further analysis. Data obtained through questionnaire were analyzed using quantitative methods. The data from the questionnaire were subjected to computation of simple statistics such as frequencies, percentages, tabulations, and cross-tabulations and presented in form of tables, graphs, and charts. 


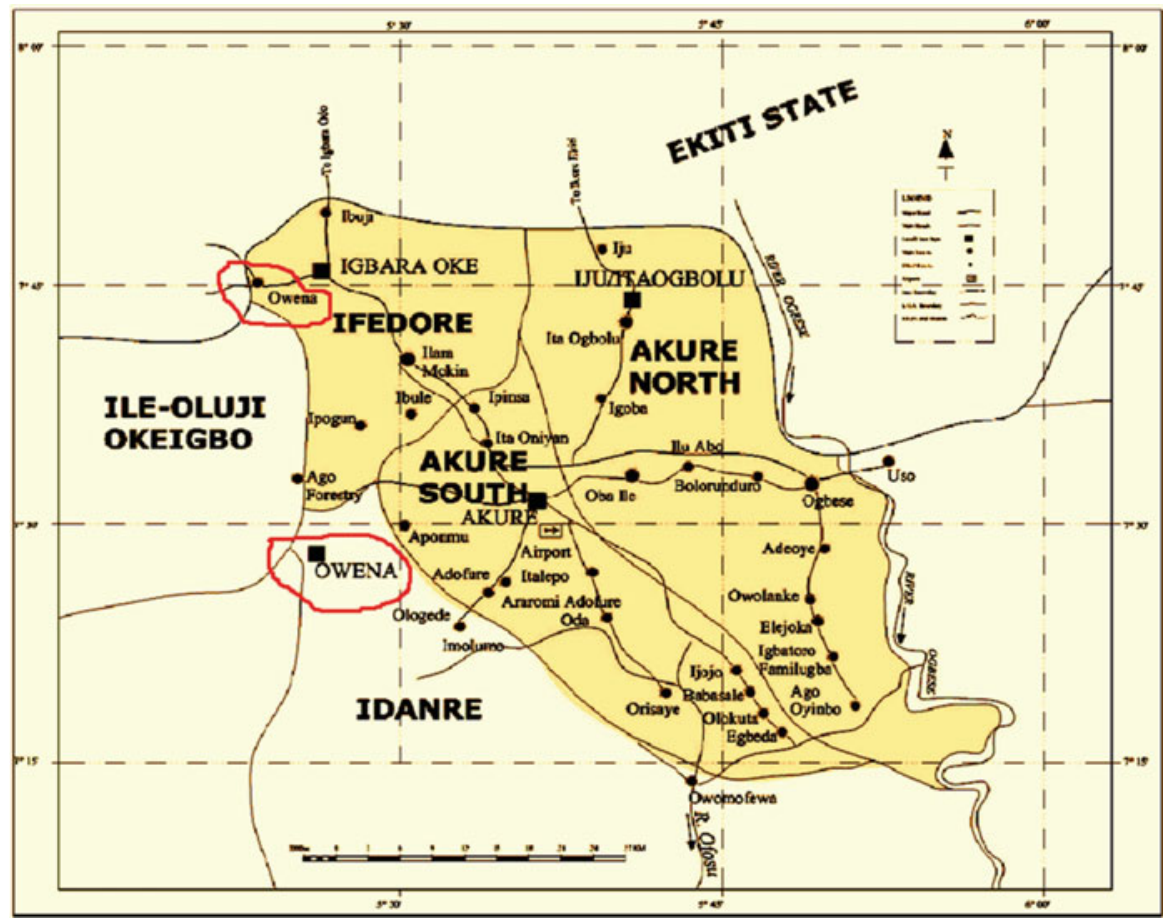

Fig. 2 Map of study area. (Source: Authors' Download: Google map, 2018)

A multistage sampling technique was used to select the samples in this chapter. The first stage involved the purposive selection of Owena Ijesa Ori Ade Osun State and Owena Market road Ondo East local Government.

\section{Cronbach Alpha}

Cronbach alpha $(\alpha)$ was used to analyze the sufficiency of the survey instrument.

$$
\text { Cronbach } s \alpha=\frac{N-\bar{C}}{\bar{V}+(N-1) \cdot \bar{C}}
$$

Where:

$N=$ No of items (12)

$\bar{C}=$ Average inter - item covariance among the items

$\bar{V}=$ Average variance

The survey instrument for this chapter is sufficient because Cronbach alpha is greater than 0.6. 


\section{Distribution According to Gender and Age Group of Respondent in Owena Osun and Ondo States}

The distribution according to gender and age group of the populace involve in fishing activities in this chapter is presented in Figs. 3 and 4, respectively. The result revealed that all of the respondent (100\%) in Owena Ondo were males, while $92 \%$ of the respondents in Owena Osun were male and $8 \%$ females. The pooled result revealed that $96 \%$ of the respondents were males while $4 \%$ were females. The high percentage of men involvement in fishing as revealed by the most of the

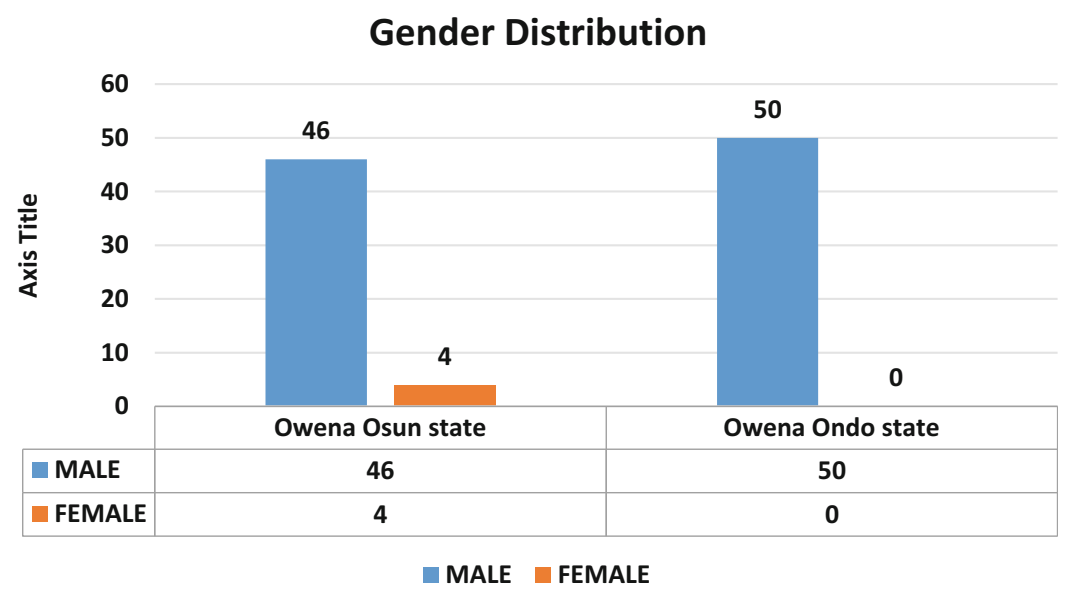

Fig. 3 Gender distribution of respondents

\section{Age Distribution of Respondents}

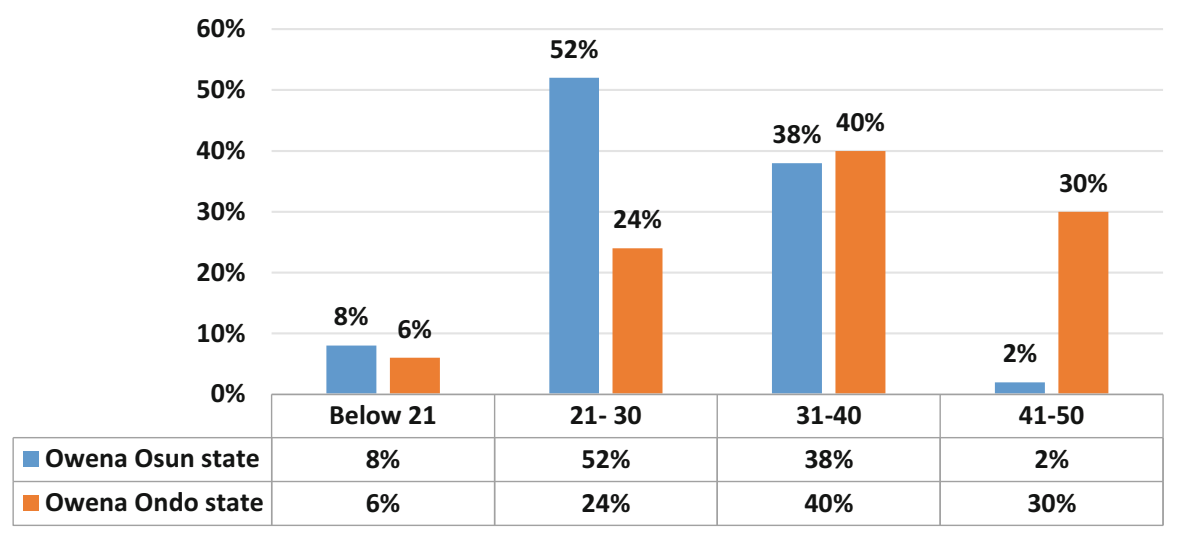

Owena Osun state $\quad$ Owena Ondo state

Fig. 4 Age distribution of respondents 
respondents in the areas attest to high-risk associated fishing. In addition, the extensive involvement of women in post-harvest fish processing and fish trading might have accounted for their low percentage in fishing in both States inland water environs.

The mainstream of the respondent (52\%) were between 21 and 31 years, $38 \%$ of the respondents were between 31 and 40 years, $8 \%<21$ years, and $2 \%$ were between 41 and 50 years. This implies that the pooled age brackets were within the age group of 21-45 years. This age bracket is considered to be the most economical, vibrant, resourceful, and productive group when considering the energy required to carry out a tedious activity like fishing and the need to source for income and livelihood.

\section{Secondary Occupation and Monthly Income of Respondent in Owena Osun and Ondo State}

The secondary occupation and monthly income of the populace involve in fishing activities in the areas is presented in Figs. 5 and 6, respectively.

Agriculture was revealed as the major source of income in both States. The chapter revealed that $60 \%$ of the respondents in Owena Osun had their secondary occupation as agriculture (fishing), followed by net mending work (22\%) and manual work (18\%), while in Owena Ondo, agriculture as secondary occupation was $78 \%$, followed by manual work $(6 \%)$, net mending $(4 \%)$, and other income sources $(2 \%)$. The monthly incomes of the respondents from fishing activities as shown in this chapter were as follows: $50 \%$ of the respondents in Owena Osun earn between $\# 25,000$ and 35,000, 26\% between \#5000 and 15,000, 14\% over \#35,000,

Fig. 5 Secondary occupation of respondent

\section{Owena Osun $\quad$ Owena Ondo}

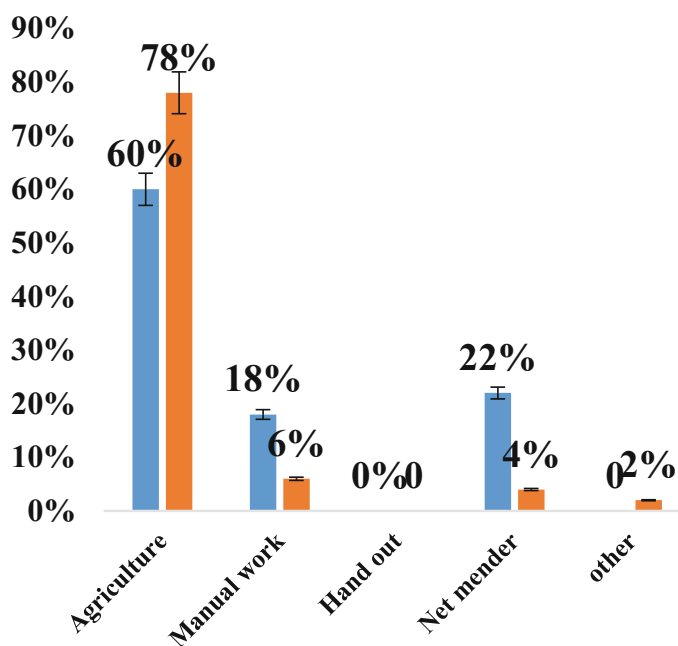


Fig. 6 Income per month of respondent
- Owena Osun $\quad$ Owena Ondo

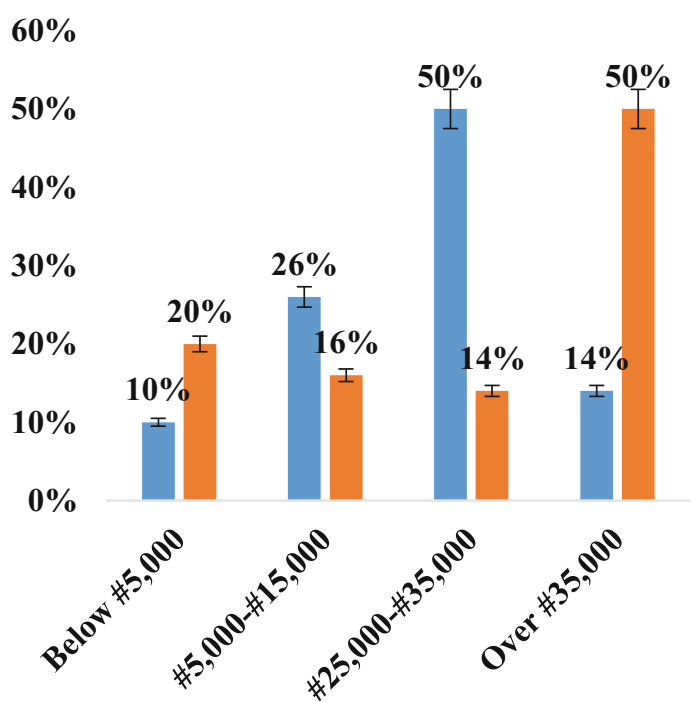

while 10\% earn below \#5000. Likewise in Owena Ondo, 50\% earn over \#35,000, $20 \%$ below \#5000 naira, 16\% between \#5000 and 15,000, and 14\% between 25,000 and 35,000 .

The result in this chapter implies that fishing activities in the area might not be sustaining the living standard of the populace and might be the reason why most of the respondents took agriculture as their secondary occupation.

\section{Effect of Climate Variability on Fish Catch in Owena Ondo and Osun States}

The effect of wind, rainfall, and temperature on fish catch in Owena Ondo and Osun States is presented in Table 1 .

The result in this chapter revealed that variability in wind patterns often affects fish catch in the aquatic ecosystem. As shown in Table $1,88 \%$ and $90 \%$ of the respondents observed that strong winds reduce fish catch in Owena Ondo and Osun State, respectively. During moderate wind, $2 \%$ and $10 \%$ of the respondents reported very low fish catch, $38 \%$ and $30 \%$ reported high catch, $20 \%$ and $10 \%$ observe very high catch, while 34\% and 50\% observe normal fish catch in Owena Ondo and Osun State, respectively. Also, the impact of waves on fish catch by respondents revealed that $52 \%$ causes regular and normal catch in the two States, while $36 \%$ and $48 \%$ cause low catch in Owena Ondo and Osun, respectively. The availability of fish for harvest in various aquatic environments is often affected by variation in wind patterns. This often results in the destruction of fishing infrastructure, 


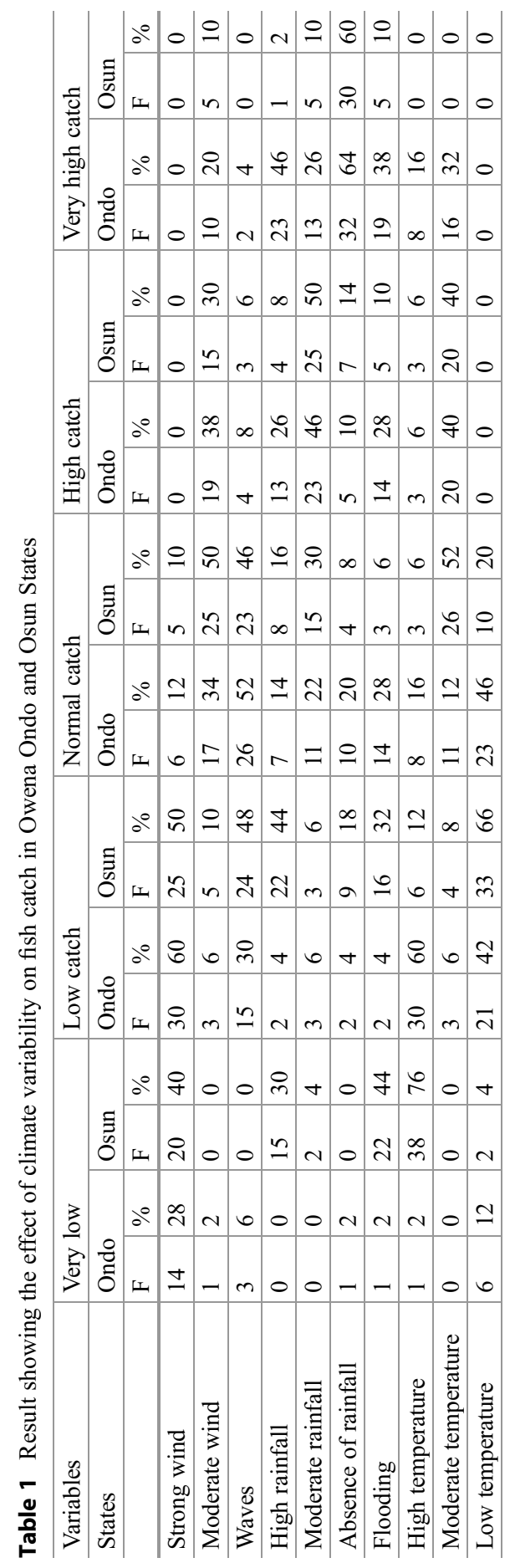


submergence/loss of fishing boats with adverse effects on fisher folks, and reduction in the number of catches. Trotman (2009) and Crandall (2009) opined that changes in wind patterns and extreme weather conditions can be damaging to fish production, distribution, abundance, and the fisheries industries as they cause destruction of the fishing gear, vessels, and biodiversity, thus becoming a major setback to the fishing community. The findings support the report of Jallow et al. (1999) who observed changes in wind pattern and adduced it to changes in climatic regimes.

There was marked variation in the rainfall pattern across the two states with different impacts on fish catch. In Owena Ondo, $46 \%$ of the respondents observed very high catch, $26 \%$ high catch, and $18 \%$ low catch during high rainfall. During moderate rainfall, $46 \%$ of the respondents observed high catch, $26 \%$ very high catch, $22 \%$ normal catch, and $6 \%$ low catch. During flooding, $66 \%$ of the respondents observed that catch is high, while $6 \%$ observe low catch. In Owena Osun, $2 \%$ of the respondents observed very high catch, $8 \%$ high catch, and $54 \%$ low catch during high rainfall. During moderate rainfall, $50 \%$ of the respondents observed high catch, $10 \%$ very high catch, $30 \%$ normal catch, and $10 \%$ low catch. $76 \%$ of the respondents observed low catch during flooding, while $20 \%$ observed high catch. Although changes in rainfall pattern have often proof to have different impacts on the duration of fishing, the high catch observed during high rainfall could be as a result of influx of fresh water which could have led to increase in fish growth and performances. In addition, many aquatic species tend to reproduce and migrate during raining seasons due to water and nutrients availability, thus supporting high biomass and catch.

Most of the respondents in both locations reported low fish catch during high and low temperature. $40 \%$ and $88 \%$ reported low fish catch during high temperature, while $19 \%$ and $6 \%$ observed high catch in Owena Ondo and Osun, respectively. Also, during low temperatures, $54 \% 70 \%$ of the respondents reported low fish catch in Owena, Ondo and Osun, respectively. The low fish catch during high and low temperature implies a warming trend in the areas. Changes in temperature can change the dynamics of aquatic environments, thus resulting in changes in the migration patterns of fish and reduced fish landings (African-Action 2007).

\section{Likely Effect of Climate Variability on Fisher Folks in Owena Ondo and Osun States}

The likely effect of climate variability such as wind, rainfall, and temperature on fisher folks in both locations is presented in Table 2.

In both locations, most of the respondents $(94 \%$ and $100 \%$ in Owena Ondo and Osun, respectively) observed and stated the adverse effect of strong winds on fisher folks. This impact varies from loss of fishing gear (traps and nets), sickness (body injuries), and death. Majority of the respondents (100\% and 98\% in Owena Ondo and Osun, respectively) preferred moderate, calm wind for their fishing activities. It was also observed by most of the respondents in both states that wave and stormy conditions lead to loss of fishing equipment. 


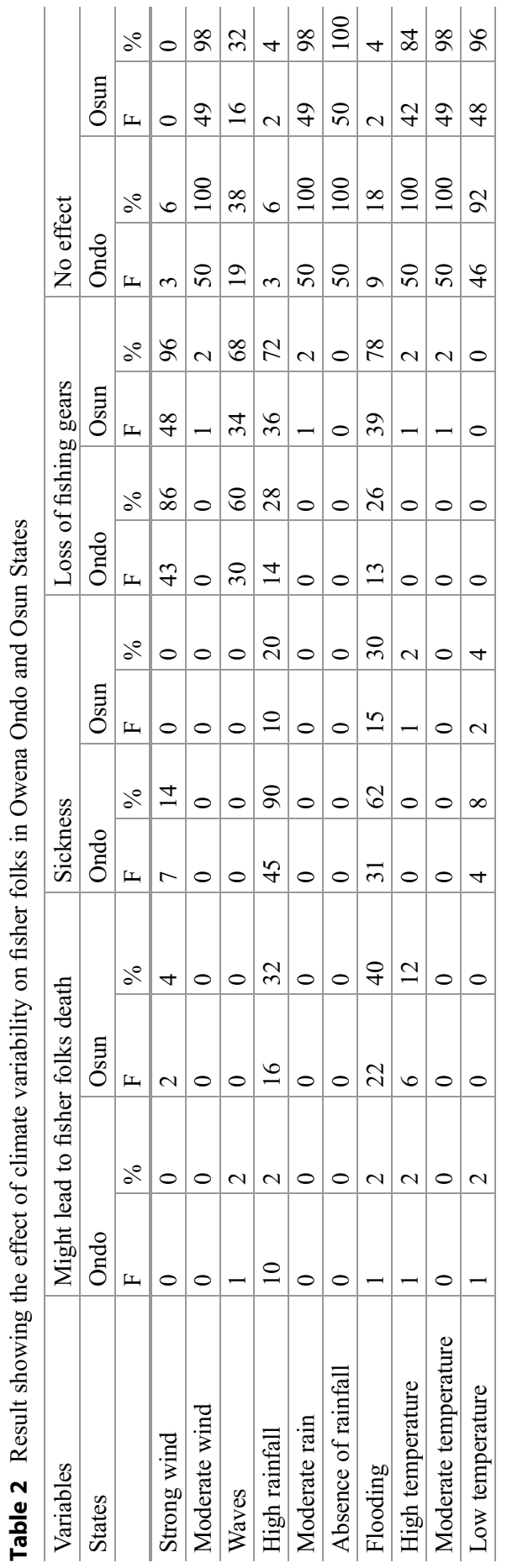


The results in this chapter also revealed the effect of changes in rainfall pattern in both locations. In Owena Ondo State, $90 \%$ of the respondents observed high rainfall which results into sickness such as cold and malaria from mosquito bite on the fisher folks, $28 \%$ observed the loss of fishing gear in waters, while $20 \%$ revealed fisher folks might die as a result of high rainfall. In Owena Osun, the majority of the respondents $(72 \%)$ observed the loss of gear during high rainfall, $32 \%$ observed that it might lead to the death of fisher folks, while $20 \%$ observed various sickness on the fisher folks. The major impact of flooding in both locations was sickness and loss of fishing gears and death.

The adverse effect of climate variability on the fisher folks was clearly evident in this chapter. The impacts of strong wind, waves, rainfall, flooding, and temperature were strongly observed by the respondents to cause sicknesses (malaria, cholera), physical injuries, destruction/loss of fishing gears, and death from boat submergence and climatic shocks. Badjeck et al. (2009, 2010) observed the same effects in their studies and noted it to be inimical to health and safety of the fisher folks and deleterious to sustainable livelihood.

\section{Effect of Climate Variability on Fishing Techniques in Owena Ondo and Osun States}

The effect of climate variability on fishing techniques in both locations is presented in Table 3.

This chapter revealed that most of the respondents observed the adverse effect of climate variability on the fishing techniques in both locations. During strong winds

Table 3 Percentage of respondents on effect of climate variability on fishing techniques in Owena Ondo and Osun States

\begin{tabular}{|c|c|c|c|c|c|c|c|c|}
\hline \multirow{3}{*}{$\begin{array}{l}\text { States } \\
\text { Variables } \\
\end{array}$} & \multicolumn{4}{|c|}{ Ondo } & \multicolumn{4}{|c|}{ Osun } \\
\hline & \multicolumn{2}{|c|}{$\begin{array}{l}\text { Normal fishing } \\
\text { method } \\
\text { (active) }\end{array}$} & \multicolumn{2}{|c|}{$\begin{array}{l}\text { Other fishing } \\
\text { method } \\
\text { (passive) }\end{array}$} & \multicolumn{2}{|c|}{$\begin{array}{l}\text { Normal fishing } \\
\text { method } \\
\text { (active) }\end{array}$} & \multicolumn{2}{|c|}{$\begin{array}{l}\text { Other fishing } \\
\text { method } \\
\text { (passive) }\end{array}$} \\
\hline & $\mathrm{F}$ & $\%$ & $\mathrm{~F}$ & $\%$ & $\mathrm{~F}$ & $\%$ & $\mathrm{~F}$ & $\%$ \\
\hline Strong wind & 13 & 40.63 & 19 & 59.38 & 7 & 16.67 & 35 & 83.33 \\
\hline Moderate wind & 19 & 59.38 & 11 & 34.38 & 34 & 80.95 & 7 & 16.67 \\
\hline Waves & 15 & 46.88 & 17 & 53.13 & 19 & 45.24 & 23 & 54.76 \\
\hline High rainfall & 11 & 34.38 & 19 & 59.38 & 16 & 38.09 & 26 & 61.9 \\
\hline Moderate rain & 18 & 56.25 & 14 & 43.75 & 37 & 88.1 & 5 & 11.9 \\
\hline Absence of rainfall & 14 & 43.75 & 18 & 56.25 & 30 & 71.43 & 12 & 28.57 \\
\hline Flooding & 14 & 43.75 & 31 & 62 & 10 & 23.81 & 32 & 76.19 \\
\hline High temperature & 15 & 46.88 & 17 & 53.13 & 37 & 88.1 & 5 & 11.9 \\
\hline Moderate temperature & 22 & 68.75 & 10 & 31.25 & 39 & 92.86 & 3 & 7.14 \\
\hline Low temperature & 19 & 59.38 & 13 & 40.63 & 32 & 76.19 & 10 & 23.81 \\
\hline
\end{tabular}


and storms, most of the respondents $(59.38 \%$ and $83.33 \%)$ do fishing using other fishing method (passive method), while $40.63 \%$ and $16.67 \%$ use normal fishing method techniques (active method) in Owena Ondo and Osun, respectively. During waves, $53.13 \%$ and $54.76 \%$ use other fishing method, while $46.88 \%$ and $45.24 \%$ use normal fishing method in Owena Ondo and Osun, respectively.

The result also revealed that fishing techniques change during high rainfall as $59.38 \%$ and $61.90 \%$ use the other techniques as opposed to the usual fishing methods in Owena Ondo and Osun, respectively. During flooding, 62\% and $76.19 \%$ use unusual fishing method, while $43.75 \%$ and $23.81 \%$ use normal fishing method in Owena Ondo and Osun, respectively.

Most of the respondents $(53.13 \%$ and $88.10 \%)$ reported the use of other methods of fishing during high temperatures, while $46.88 \%$ and $11.09 \%$ reported the use of the usual methods of fishing in Owena Ondo and Osun, respectively.

The effect of climate variability was visible on the various methods and techniques of fishing. The techniques of fishing referred to as the normal methods of fishing include the use of cast nets, gill nets, hand lines, and beach seine nets that is the active fishing, while the other methods of fishing include trapping, long line fishing, and use of baskets, i.e., the passive fishing.

\section{Effect of Variability in Climate on Choice of Fishing Equipment in Owena Ondo and Osun States}

The effect of climate variability on the choice of fishing equipment in both locations is presented in Table 4.

Table 4 Percentage response of respondents on the effect of climate variability on fishing equipment in Owena Ondo and Osun

\begin{tabular}{|c|c|c|c|c|c|c|c|c|c|c|c|c|}
\hline \multirow{3}{*}{$\begin{array}{l}\text { Variables } \\
\text { States }\end{array}$} & \multicolumn{4}{|c|}{$\begin{array}{l}\text { Destruction of } \\
\text { fishing gears }\end{array}$} & \multicolumn{4}{|c|}{$\begin{array}{l}\text { Sinking of fishing } \\
\text { gears }\end{array}$} & \multicolumn{4}{|c|}{ No effect on equipment } \\
\hline & \multicolumn{2}{|c|}{ Ondo } & \multicolumn{2}{|c|}{ Osun } & \multicolumn{2}{|c|}{ Ondo } & \multicolumn{2}{|c|}{ Osun } & \multicolumn{2}{|c|}{ Ondo } & \multicolumn{2}{|c|}{ Osun } \\
\hline & $\mathrm{F}$ & $\%$ & $\mathrm{~F}$ & $\%$ & $\mathrm{~F}$ & $\%$ & $\mathrm{~F}$ & $\%$ & $\mathrm{~F}$ & $\%$ & $\mathrm{~F}$ & $\%$ \\
\hline Strong wind & 44 & 88 & 28 & 56 & 3 & 6 & 20 & 40 & 3 & 6 & 2 & 4 \\
\hline Moderate wind & 0 & 0 & 0 & 0 & 0 & 0 & 1 & 2 & 50 & 100 & 49 & 98 \\
\hline Waves & 33 & 66 & 20 & 40 & 3 & 6 & 15 & 30 & 16 & 32 & 15 & 30 \\
\hline High rainfall & 5 & 10 & 15 & 30 & 37 & 74 & 36 & 72 & 12 & 24 & 5 & 10 \\
\hline Moderate rain & 0 & 0 & 0 & 0 & 0 & 0 & 1 & 2 & 50 & 100 & 49 & 98 \\
\hline Absence of rainfall & 0 & 0 & 0 & 0 & 0 & 0 & 2 & 4 & 50 & 100 & 48 & 96 \\
\hline Flooding & 18 & 36 & 30 & 60 & 26 & 52 & 34 & 68 & 15 & 30 & 5 & 10 \\
\hline High temperature & 0 & 0 & 4 & 8 & 0 & 0 & 0 & 0 & 50 & 100 & 46 & 92 \\
\hline $\begin{array}{l}\text { Moderate } \\
\text { temperature }\end{array}$ & 0 & 0 & 0 & 0 & 0 & 0 & 0 & 0 & 50 & 100 & 50 & 100 \\
\hline Low temperature & 0 & 0 & 0 & 0 & 0 & 0 & 0 & 0 & 50 & 100 & 50 & 100 \\
\hline
\end{tabular}


This chapter revealed that strong winds destroy $88 \%$ and $66 \%$ fishing equipment, $6 \%$ and $40 \%$ causes sinking of gears in Owena Ondo and Osun state, respectively. $66 \%$ and $40 \%$ of the respondents revealed the impact of waves on the destruction of fishing equipment in Owena Ondo and Osun, respectively. Also, $74 \%$ and $52 \%$ of the respondents showed that fishing equipment sink during high rainfall and high flooding, respectively, in Owena Ondo, while $72 \%$ and $68 \%$ reported the same scenario in Owena Osun. The effect of climate variability on the fishing equipment was strongly observed in the areas. The loss of physical capital equipment (gears and nets) compounded with a deteriorating financial asset base from strong winds, waves, and high rainfall would have had a significant effect on livelihoods in the areas.

The periods of moderate winds and rainfall were observed by the respondents to be the most convenient and secure for fishing equipment. However, temperature variations were observed to have no effect on the fishing equipment in both locations.

\section{Climatic Trends in Owena River Between 2008 and 2017: Wind Trends and Rainfall Pattern in Owena Osun State Between 2008 and 2017}

The statistical records on wind and rainfall data were obtained from the Department of Meteorological/Climate Science Technology Department of the Federal University of Technology, Akure, Nigeria, as presented in this chapter. Figure 7 shows the monthly trend of wind data for Owena Osun (2008-2017); Fig. 8 shows annual rainfall pattern/data for Owena Osun State (2008-2017); and Fig. 9 shows monthly rainfall pattern/data for Owena Osun State: 2008-2017. The record reveals over the 10 years duration of the wind trends and rainfall pattern. For the 10 years under consideration (between 2008 and 2017), a decreased trend in the average wind speed across the months from September to December was observed. The highest wind speed was in the month of March and the lowest wind speed in the month of June.

Also, the recorded data on rainfall from 2008 to 2017 showed an increasing trend in annual rainfall. The irregularity in rainfall pattern from these records points a clear indication to weather and climate variability; some years like 2014, 2015, and 2011 have exceptionally high average rainfall. These trends certainly will affect fishing activities. More so, fluctuation in the pattern of rainfall will have both positive and negative impacts on fish catch in the inland Owena water. As opined by Adeleke and Fagbenro (2013), fluctuations in the climate variables will pose adverse effect on the fisher folks and fisheries activities in the coastal areas of Nigeria. In addition, strong winds according to Jallow et al. (1999) have adverse effects on fishing infrastructure as fishing vessels get destroyed, lost, or submerge 


\section{MONTHLY WIND SPEED(MS-1) OF OWENA OSUN \\ FROM 2008-2017}

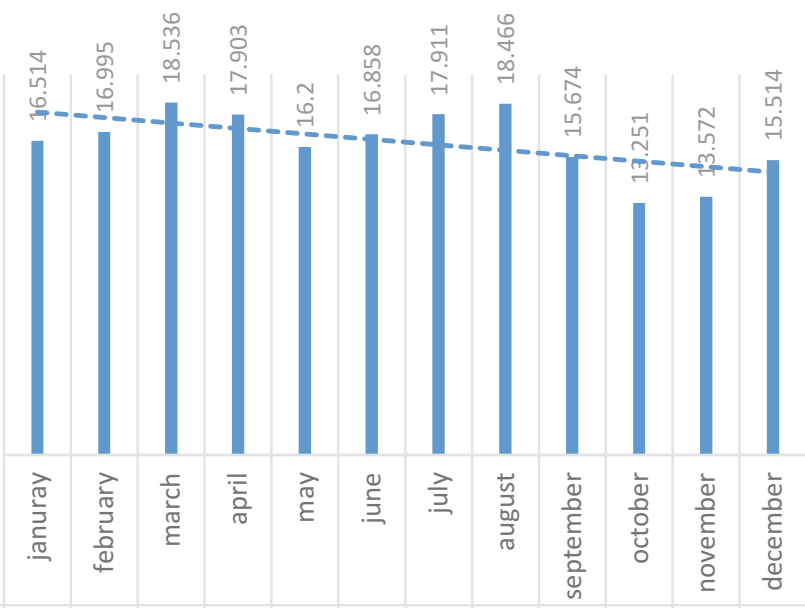

\begin{tabular}{ll|l|l|l|l|l|l|l|l|l|l|l}
\hline monthly wind speed(ms-1) & 16.514 & 16.995 & 18.536 & 17.903 & 16.2 & 16.858 & 17.911 & 18.466 & 15.674 & 13.251 & 13.572 & 15.514
\end{tabular}

Fig. 7 Monthly trend of wind data for Owena: 2008-2017. (Source: Climate Records of Department of Meteorological/Climate Science Technology, The Federal University of Technology, Akure. Nigeria, 2018)

\section{Conclusion}

This chapter revealed that climate variability has affected fishing activities, fisheries resources, and structures in Owena Osun and Ondo State. The potential impacts of climate change range from impact on the fisher folk, some of which are loss and destruction of fishing equipment's, impact on health, alteration in fishing duration, alteration in fish catch, and change in fishing techniques and equipment. It was also observed that the success and optimum benefit derived from fishing is dependent on favorable climatic conditions. Fisher folk and fishermen that depend on fisheries resources as a source of livelihood will continue to be at risk if proper preventive strategies and measures against the adverse effect of climate and food insecurity are not set in place. This chapter, therefore, recommends the need for extension education and innovation on the various possible strategies, fishing techniques, equipment, and beneficial knowledge to help fisher folks to be able to counter or lessen the adverse effect of climate variability in order for fisher folks to attain maximum sustainable catch. 


\section{ANNUAL RAINFALL (M)}

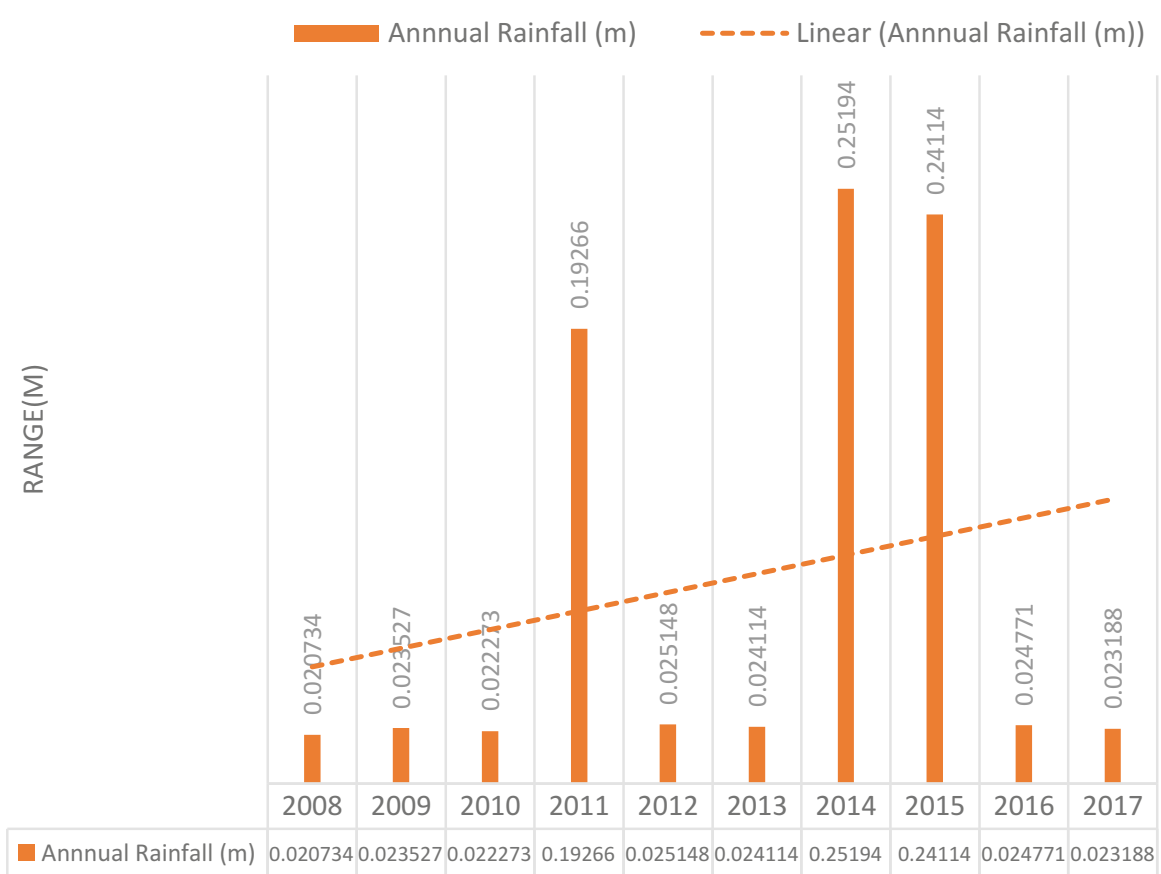

Fig. 8 Annual rainfall pattern/data for Owena Osun State: 2008-2017. (Source: Climate Records of Department of Meteorological/Climate Science Technology, The Federal University of Technology, Akure. Nigeria, 2018)

\section{MONTHLY RAINFALL OF OWENA ONDO STATE}

FROM 2017-2018

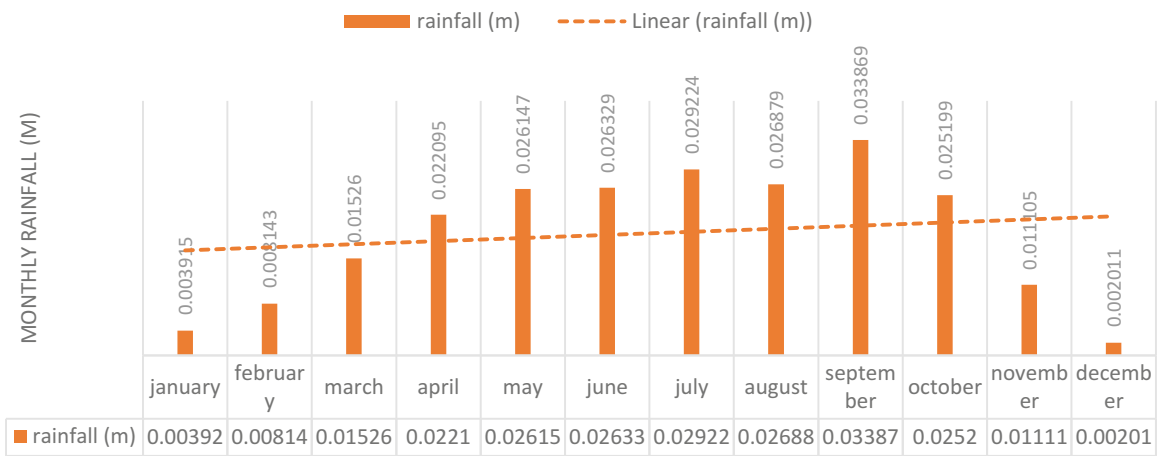

Fig. 9 Monthly rainfall pattern/data for Owena Osun State: 2008-2017. (Source: Climate Records of Department of Meteorological/Climate Science Technology, The Federal University of Technology, Akure. Nigeria, 2018) 


\section{References}

Adeleke ML, Balogun AA (2013) Occurrence of climate change and its effects on the fishing activities in the coastal region of Ondo State, Nigeria. Int J Dev Econ Sustain 1(1):1-13

Adeleke ML, Fagbenro OA (2013) Livelihood diversification and operational techniques of the Artisanal Fisherfolks in the coastal region of Ondo State, Nigeria. Int J Innov Res Dev 2(1):262 273. ISSN 2278-0211(online)

Adeleke ML, Omoboyeje VO (2016) Effects of climate change on aquaculture production and management in Akure Metropolis, Ondo State, Nigeria. Niger J Fish Aquac 4(1):50-58

Africa-Action (2007) Africa policy outlook. Available at http://www.africaaction.org

Agbebi FO, Omoniyi AO (2011) Effect of climate change and coping strategies on socio economic status of fisher folks in Ilaje-Ese Odo local government areas of Ondo State, Nigeria. Int J Sci Nat 2(2):339-343

Allison EH, Perry AL, Badjeck M-C, Adger WN, Brown K, Conway D (2009) Climate change and fisheries: a comparative analysis of the relative vulnerability of 132 countries. Fish Fish 10 (2):173-196

Badjeck M-C, Mendo J, Wolff M, Lange H (2009) Climate variability and the Peruvian scallop fishery: the role of formal institutions in resilience building. Clim Chang 94(1-2):211-232

Badjeck M-C, Allison EH, Halls AS, Dulvy NK (2010) Impacts of climate variability and change on fishery-based livelihoods. Mar Policy 34:375-383

Cheung WWL, Lam VWY, Sarmiento JL, Kearney K, Watson R, Pauly D (2009) Projecting global marine biodiversity impacts under climate change scenario. Fish Fish 10:235-251

Crandall A (2009) Local perceptions of water variability and wetlands in Lake Victoria. Institute for the Study of Diplomacy Edmund A. Walsh School of Foreign Service Georgetown University. Washington DC, USA

Idowu AA, Ayoola SO, Opele AI, Ikenweiwe NB (2011) Impact of climate change in Nigeria. Iran J Energy Environ 2(2):145-152

Jallow BP, Toure S, Barrow MMK, Matheiu AA (1999) Coastal zone of the Gambia and the Abuja Region in cote d'Ivore: sea rise and vulnerability, response strategies, and adaptation options. Clim Res 12(2-3):129-138

Perry RI, Ommer RE, Allison E, Badjeck MC, Barange M, Hamilton L (2009) The human dimensions of marine ecosystem change: interactions between changes in marine ecosystems and human communities. In: Barange M, Field C, Harris R, Hofmann E, Perry I, Werner C (eds) Global change and Marine ecosystems. Oxford University Press, Oxford

Trotman A, Gordon RM, Hutchinson SD, Singh R, McRae-smith D (2009) Policy responses to GEC impacts on food availability and affordability in the Caribbean community. Environ Sci Policy 12(4):529-541

World Fish Center (WFC) (2006) The threat to fisheries and aquaculture from climate change. World Fish Center policy brief. WFC, Penang, p 8

Open Access This chapter is licensed under the terms of the Creative Commons Attribution 4.0 International License (http://creativecommons.org/licenses/by/4.0/), which permits use, sharing, adaptation, distribution and reproduction in any medium or format, as long as you give appropriate credit to the original author(s) and the source, provide a link to the Creative Commons license and indicate if changes were made.

The images or other third party material in this chapter are included in the chapter's Creative Commons license, unless indicated otherwise in a credit line to the material. If material is not included in the chapter's Creative Commons license and your intended use is not permitted by statutory regulation or exceeds the permitted use, you will need to obtain permission directly from the copyright holder.

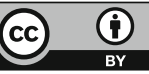

